\title{
HYBRID NAPIER (Pennisetum perpureum X Pennisetum americarnum) VAR. CO-3: A RESOURCEFUL FODDER GRASS FOR DAIRY DEVELOPMENT IN SRI LANKA
}

\author{
S. Premaratne ${ }^{1}$ and G.G.C. Premalal ${ }^{2}$
}

\begin{abstract}
Less availability of good quality green forages has led to low productivity from national dairy herd of Sri Lanka. Growing fodder to suit the particular production system is an efficient and economical solution for this problem. Hybrid Napier var. $\mathrm{CO}-3$ is a high yielding perennial fodder grass developed by the Tamil Nadu Agricultural University, Coimbatoor, India in 1997. The Livestock Breeding Project introduced this fodder crop to Sri Lanka in 1999.

This grass is placed in a higher category, especially on tillering capacity, green forage yield, regeneration capacity, leaf to stem ratio, crude protein content, in resistance of pest and diseases and in free from adverse factors along with other fodder varieties grown in the country. It recorded an average green fodder of $5-8$

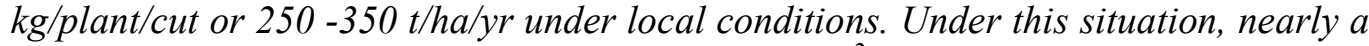
block of 500 grass bushes (approximately $500 \mathrm{~m}^{2}$ or 20 perches land area) is adequate to supply year-round quality fodder without concentrates for two milking cows.
\end{abstract}

This grass is propagated through root-slips or stem-cuttings and could be maintained as a perennial crop up to 4 - 5 years. Endowed with quick regeneration capacity, it can be harvested once in 30 - 45 days. Proper management practice together with correct application of fertilizer, irrigation in drought spells, cutting at the suitable height and interval is essential for maximum profit and persistence of the crop. When harvested at correct stage, CO-3 grass contains $18-20 \%$ dry matter and $15-16 \%$ crude proteins, 9.8 - 12.8\% ash, 34 - 37\% crude fiber and $74-78 \%$ neutral detergent fiber on dry matter basis. Surprisingly high crude protein content is one of a distinctive feature of this grass.

The Department of Animal Production and Health, Veterinary Research Institute, Gannoruwa and Department of Animal Science, Faculty of Agriculture, University of Peradeniya have launched research and development activities under field situation to investigate the potentials and limitations under on-farm conditions and popularize the grass among small holders.

Key words: Green fodder, Hybrid Napier var. CO-3, Tillering capacity, Green forage yield, Regeneration capacity, Leaf to stem ratio, Crude protein content

\section{INTRODUCTION}

Resembling the other South and Southeast Asian countries, in Sri Lanka, low productivity of dairy animals could be accredited to the less availability of forage together with poor quality. To maximize the milk production, it is essential to feed animals with quality green fodder. Consequently, high yielding forages including number of varieties of

${ }^{1}$ Professor of Animal Science, Department of Animal Science, Faculty of Agriculture, University of 22

Peradeniya. Sri Lanka

${ }^{2}$ Head, Division of Pasture \& Fodder, Veterinary Research Institute, Gannoruwa, Sri Lanka 
Napier hybrids have been introduced recently. Due to various reasons, growing forage crops is a new concept for most of farmers, unlike growing food and other cash crops.

Hybrid Napier var. CO-3 was developed by the scientists at Tamil Nadu Agricultural University (TNAU) at Coimbatoor and released for commercial cultivation in 1997 (TNAU, 2003). Later Animal Husbandry Department, Govt. of Tamil Nadu has taken up activities to popularize this grass among farmers (Policy Note, 2005/2006). It is an inter-specific hybrid between Bajra (Pennisetum americanum L.) and a selection of a common Napier (Pennisetum purpureum Schum.). It is one of the highest yielding perennial tropical fodder grasses and considered as cut-and-carry forage for stall feeder systems. It is superior to other Napier varieties, NB-21 and Clone -13, which was grown by some farmers in Sri Lanka in the past. The characteristic features of CO-3 fodder grass are: profuse tillering, high yield potential, high dry matter and crude protein content, quick regeneration capacity, high leaf to stem ratio, high palatability, free from pest and diseases and low in adverse factors. This grass is introduced to Sri Lanka in 1999 by the Livestock Breeding Project (functioned under the Ministry of Agriculture \& Livestock) to boost its forage development activities (Annual report, LBP, 2000).

This paper discusses the basic agronomy, establishment and management aspects, nutritive quality, current research and development activities and other related aspects of this resourceful fodder grass, in ensemble the Sri Lankan dairy farmer.

\section{DISCUSSION}

\section{Hybrid Napier grasses and the variety} CO-3

\section{Napier grass hybridization}

Bajra or Pearl millet, Pennisetum glaucum L. $(2 \mathrm{n}=14)$, is a coarse annual bunch grass and is grown in Asia and Africa primarily for grain and in some regions of America for feed and forage for animals (Gupta \& Mhere, 1997).This grass is resistant to drought and, most of pest and diseases (Bogdan,1977). Napier or Elephant grass, $P$. purpureum Schum. $(2 \mathrm{n}=28)$, is a robust perennial grass grown for forage mainly in tropical areas of Africa, Asia, South and Central America. Napier grass is forming large broad clumps. Its stems are tall and up to $3 \mathrm{~cm}$ in diameter in the lower part (Bogdan, 1977). It was first introduced to Sri Lanka from India in 1950s at Maha Illuppallama Dry Zone Research Station (Pathirana, 1970). This grass is deep rooted and drought resistant and as a fodder it has a very long world history (Bogdan, 1977).

The hybridization between pearl millet and Napier is known to occur naturally since these are protogynous and crosspollinate. It was showed that these two species readily cross and that the resultant interspecific hybrids are more vigorous than the parent species and are highly sterile $(2 n=21)$. Thus, it can be propagated as a forage plant without danger of becoming a weed, as is the case with Napiers (Gupta \& Mhere, 1997). 


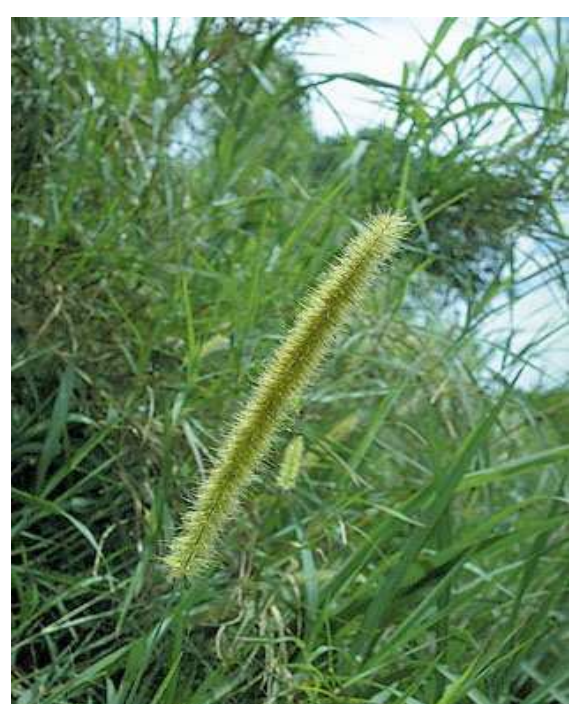

(a) Napier grass

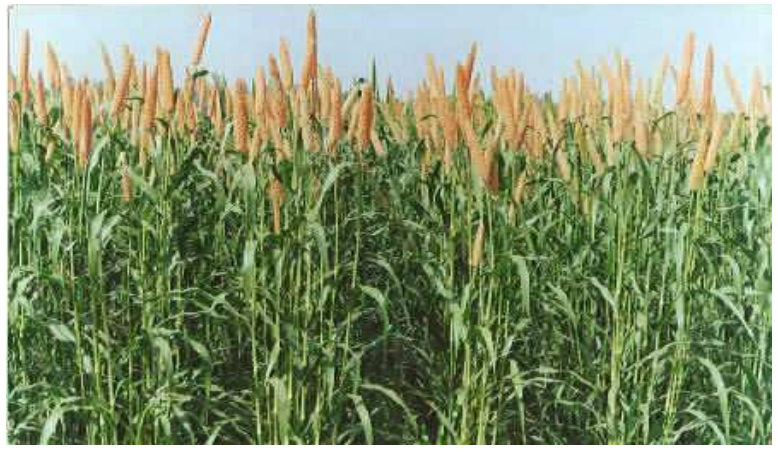

(b) Bajra grass

Figure 01: Napier grass and Bajra grass

According to Gupta \& Mhere, 1997, several workers have reported the potential for improvement in yield and quality of Bajra $x$ Napier hybrids over Napier. They have also observed that the dry matter (DM) yield of hybrids from the cross Bajra $x$ Napier were comparable with common Napier and its selections. These varieties produce more tillers and leaves with bulk of fodder and, grow faster than their parents (Gupta \& Mhere, 1997). Forage quality of most of these hybrids was also superior to their ancestors (Narayanan \& Dabadghao, 1972). The parental materials of both Bajra and Napier have now been improved worldwide, making it possible to develop better hybrids in terms of quality and yield.

During 1989 and 2000, various forage breeding institutions in the world have developed vast number of Bajra $\mathrm{x}$ Napier hybrids. Scientists of the Southern African Development Community (SADC), International Crops Research Institute for the Semi-
Arid Tropics (ICRISAT), Sorghum and Millet Improvement Programme (SMIP) in Zimbabwe and Punjab Agricultural University (PAU) and Tamil Nadu Agricultural University (TNAU) in India were the pioneers of this effort.

Table 01 summarizes the recently released Bajra-Napier hybrid varieties from India

\section{Climatic and Soil requirements}

Similar to other hybrid Napier varieties, CO-3 grass grows best in high rainfall areas (in excess of 1500 $\mathrm{mm}$ per year). It prefers a deep fertile soil and when it is established, soils or lands in eroded and rocky, water logged, salt affected and very acidic should be avoided. Optimum temperature for growth is usually 25 $40 \mathrm{C}^{0}$ and grows better in full sunlight. The grass is very susceptible to frost.

Therefore, agro ecological basis, it could be recommended for the normal agricultural soils in wet and intermediate parts of the country. It is 
recommended for the dry zone only if irrigation facilities are available. However, even in wet zone, it should be irrigated if drought spell exceeds more than a week for potential yield in the particular growth period. Usually, this grass is not recommended for hilly areas of which especially in $1500 \mathrm{~m}$ above the sea level due to its frost susceptibility, limitations of sunlight and temperature in the area and extremely acidic level in soils for the optimum grass growth.

Table 01: Bajra-Napier hybrid varieties released during 1989 - 2000 in India

\begin{tabular}{|c|c|c|c|}
\hline $\begin{array}{l}\text { Variety } \\
\text { and Station }\end{array}$ & $\begin{array}{l}\text { Year of } \\
\text { release }\end{array}$ & $\begin{array}{l}\text { Green forage } \\
\text { yield }\left(\mathrm{t} \mathrm{ha}^{-1}\right)\end{array}$ & Specific features \\
\hline $\begin{array}{l}\text { PBN-83 } \\
\text { (PAU) }\end{array}$ & 1989 & $125-170$ & Resistant to major diseases and insect pests \\
\hline $\begin{array}{l}\mathrm{CO}-2 \\
\text { (TNAU) }\end{array}$ & 1995 & $120-180$ & Resistant to major diseases and insect pests \\
\hline $\begin{array}{l}\text { PGG-101 } \\
\text { (PAU) }\end{array}$ & 1995 & $80-145$ & Free form all major diseases and insect pests \\
\hline $\begin{array}{l}\text { CO-3 } \\
\text { (TNAU) }\end{array}$ & 1997 & $130-300$ & $\begin{array}{l}\text { Resistant to major diseases and insect pests } \\
\text { and other features noted in this paper }\end{array}$ \\
\hline $\begin{array}{l}\text { PGG-518 } \\
\text { (PAU) }\end{array}$ & 1997 & $120-130$ & $\begin{array}{l}\text { Apomictic. Multicut summer fodder. } \\
\text { Resistant to insect pests and diseases. }\end{array}$ \\
\hline $\begin{array}{l}\text { PBN-233 } \\
\text { (PAU) }\end{array}$ & 1999 & $150-200$ & Resistant to major diseases and insect pests \\
\hline $\begin{array}{l}\text { PG-616 } \\
(\mathrm{PAU})\end{array}$ & 2000 & $80-120$ & $\begin{array}{l}\text { Apomictic. Multicut summer fodder. } \\
\text { Resistant to insect pests and diseases. } \\
\text { Resistant to lodging }\end{array}$ \\
\hline
\end{tabular}

(Source: Rearranged from TNAU reports, 2002)

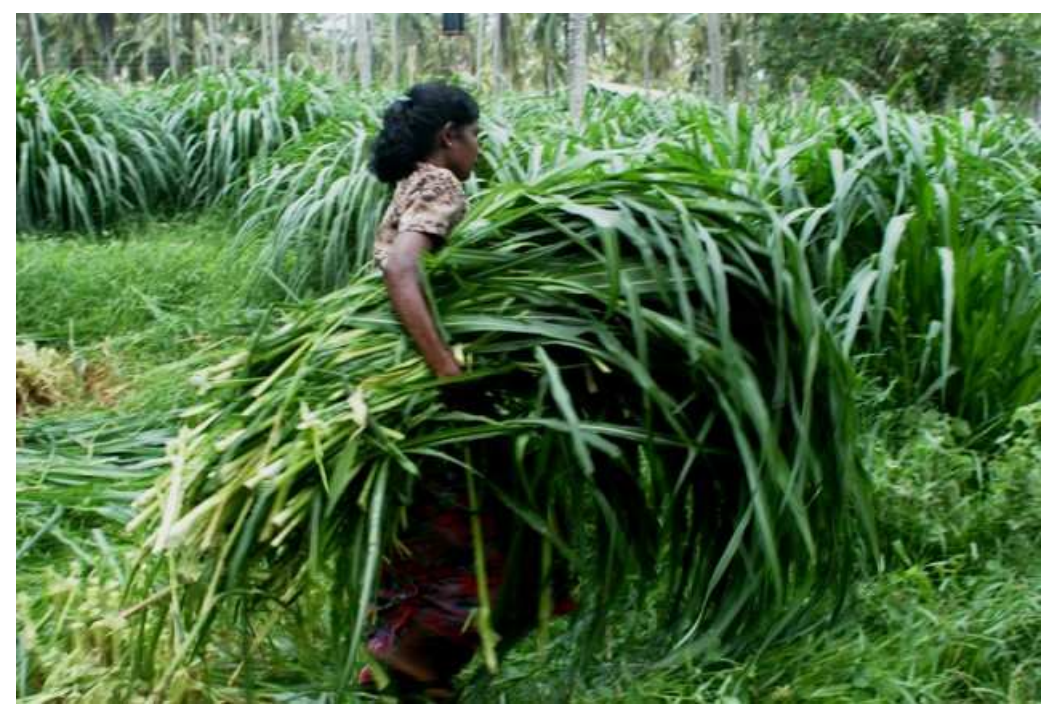

Figure 02: Well managed CO-3 fodder grass block at Rukattana NLDB farm, Bingiriya 


\section{Establishment and Management}

\section{Planting materials}

This inter-specific hybrid is sterile and does not produce viable seeds although it could initiate an inflorescence or spike. It is vegetatively propagated by root-slips or stem-cuttings and this helps to preserve its genetic purity. For quality planting materials, root-slips and stem cuttings supposed to be in fresh status and, with 3-4 active tillers
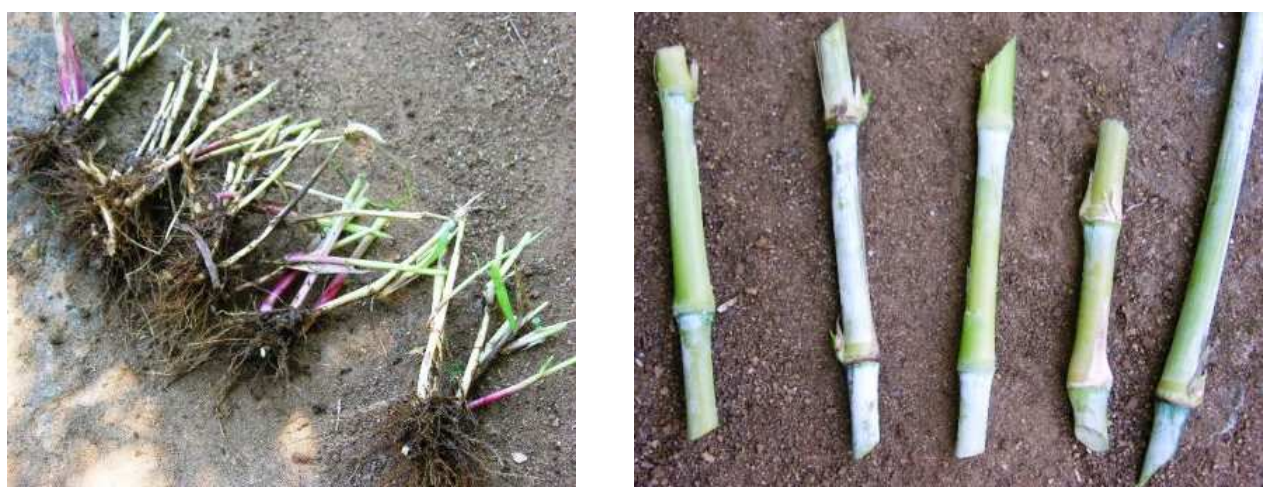

(a) Root-slips

Figure 03: Planting materials

\section{Establishment}

Grass should be planted at the beginning of the rainy season. According to the rainfall pattern in the region, farmer could come to a decision on the planting time. Rootslips or stem-cuttings are planted at a distance of $60 \times 90 \mathrm{~cm}, 90 \times 90 \mathrm{~cm}$ or $90 \times 120 \mathrm{~cm}$ depending on the soil status and other inputs (e.g. water and fertilizer) used by the farmer. One root-slip or two stem cuttings are planted in a single hole or spot on above spacing. A small portion of rootslip or upper node of stem cutting should remain with the soil level. Stem cuttings should preferably be planted vertically, slantingly, or horizontally. Land preparation could be adjusted on the land extent and farmers preference. and two nodes, respectively. Using the planting materials soon after removing them from mother plants is recommended. As a confident amount of food and water reserve should be available with the planting material for sprouting of buds and initial growth, it is also recommended not to get materials from over aged nurseries. Approximately, 10,000 - 11,000 rootslips $(1500 \mathrm{~kg})$ or $20,000-22,000$ stem-cuttings $(1600 \mathrm{~kg})$ are sufficient for establishment of a 1-hectare crop. (b) stem-cuttings

However, land preparation should facilitate the rooting and nutrient absorption environment of the newly planted root-slip or stem cutting. Followings are the recommended methods for $\mathrm{CO}-3$ grass panting.

\section{Easy planting method}

This planting method is suitable and recommended for large-scale establishments. Land should firstly be ploughed and harrowed up to 10-12 inches in depth. Cuttings are planted through furrows prepared next to harrowing.

\section{Single pit "Tambukiza" method}

This method is called "Tambukiza" and has been developed in Kenya for 
Napier grass planting and recommended for small-scale fodder planting (Tambukiza, 2002).

Pits should be made at $30 \times 30 \times 30 \mathrm{~cm}$ pits and the spacing between pits could be selected as mentioned above. Topsoil portion is separated from sub soil and then mixed $2 \mathrm{~kg}$ of organic manure (e.g. Cow dung, compost, poultry litter etc.) with topsoil and filled the pit. At the top of each pit, about $15 \mathrm{~cm}$ unfilled space should be left.

Few adaptive trials on this method were carried out recently by The
Veterinary Research Institute under on-farm and on-station conditions and obtained satisfactory results.

\section{Continuous pit "Tambukiza" method}

This is an alternative method of single pit type and recommended for smallscale farming. Pits are dug $30 \mathrm{~cm}$ in depth and width. Length of the pit should be set aside on the land size. Then it is separated the top soil and mixed with organic manure and filled the pits as the above method. Unfilled space as above should also be left.

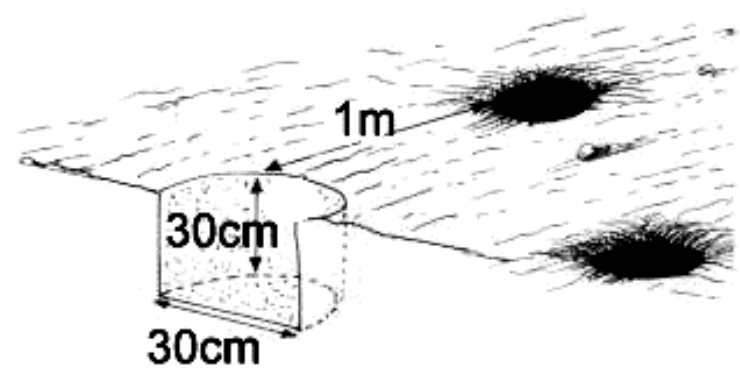

Figure 04: Single Pit "Tambukiza" method

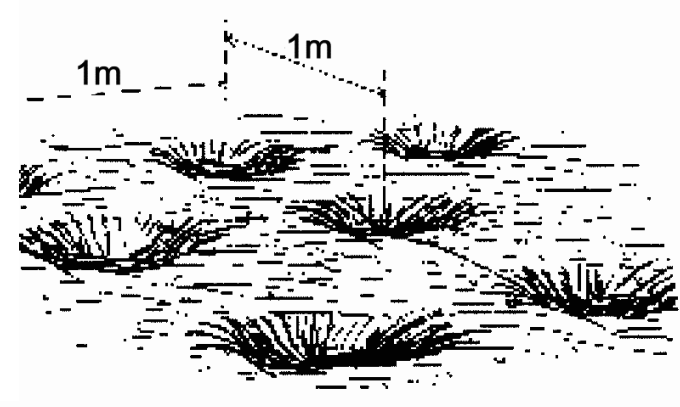

Pits $1 \mathrm{~m} \times 1 \mathrm{~m}$

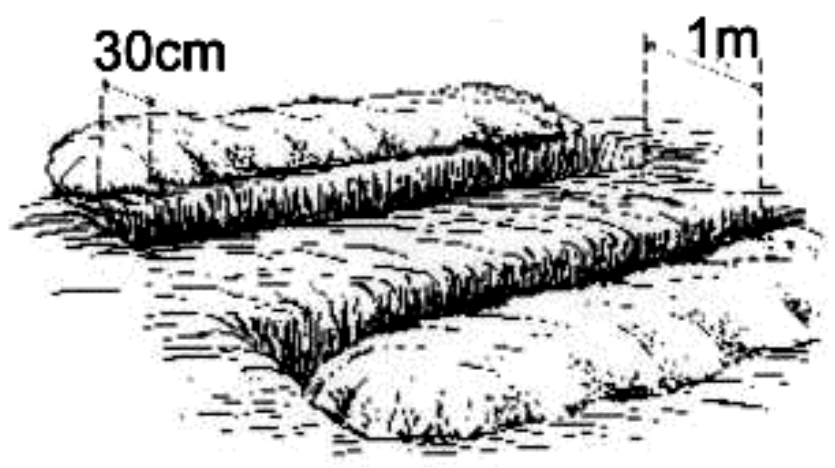

Figure 05: Continuous pit "Tambikiza" method 


\section{Fertilizer application}

Regular pattern of fertilizer application should always be followed by the farmers for this high yielding grass. Thairu and Tessema (1985) reported that managing high yielding forages without fertilizer is extremely impossible even in normal soil and rainfall conditions. Since this grass is a heavy yielder, it requires high doses of nutrients. On the other hand, nutrient management has pronounced effect on yield and quality of the fodder grass. Even under normal soils, it is essential to maintain the soil nutrient levels to go with the forage removal. Further, balanced nutrient supply also ensures utilization of all nutrients. In general, a crop of common Napier grass removes $463 \mathrm{~kg}$ of nitrogen, $96 \mathrm{~kg}$ of phosphorus and $594 \mathrm{~kg}$ of potassium per hectare per year (Walmsley et al., 1978). They also suggested that highest yields could be expected from applying nitrogen after every cut. It has been observed that basal application of recommended NPK fertilizer has given higher establishment percentage and a higher yield of $359.7 \mathrm{t} / \mathrm{ha} / \mathrm{yr}$.

As this grass is a heavy user of soil inputs, some farmers are unwilling to handle of this type of high yielding fodder grasses. Although this grass responds very quickly for inorganic fertilizer, livestock manure that could be supplied with in the farmer premises is an important resource for grass cultivation. These materials also help to improve soil physical properties and increase the activity of beneficial soil microbes. It is reported that hybrid Napier grass fertilized with adequate organic manure especially poultry manure $(2.62 \%$ nitrogen, $2.8 \%$ phosphorus and $2.82 \%$ potash) produced higher yield than those applied with inorganic fertilizer (Jayanthi, 2003). It has been also reported that application of $20 \mathrm{t} / \mathrm{ha}$ (or $2 \mathrm{~kg} /$ plant) of farmyard manure before plating grass cuttings had increased overall production of Napier grass crop (Sidhy, 2003). However, studies on organic manure application particularly in CO-3 grass under local conditions or in out side are deficient. More ever, authors have been observed that most of farmers of the country had learned about the benefit of organic manures through their experiences.

However, a fertilizer application pattern tested and recommended by the Veterinary Research Institute (VRI), Gannoruwa, Peradeniya for CO-3 grass is included in Table 2.

\section{Yield \& harvesting}

For efficient management and utilization of the crop, harvesting pattern is important. In a wellestablished crop, the first cut is ready in 60 days and subsequent cuttings are taken approximately at an interval of $30-45$ days. If the crop gets more mature it becomes lignified and decrease the palatability and digestibility. Therefore, it is recommended to harvest the crop at right stage to feed animals and, make silage if in excess. Fodder of CO-3 grass, like other Napier hybrids, should be cut close to the ground or the stubble height should not be more than $5-8 \mathrm{~cm}$.

Jayanthi (2003), in India, observed that a CO-3 crop planted on furrow and buried gave the highest green fodder yield of $375,3 \mathrm{t} / \mathrm{ha} / \mathrm{yr}$ while the lowest was recorded when the two nodal stem cuttings were planted vertically in ridges. However, adaptive experiments on furrow and buried planting in local condition are lacking and it is impossible to give recommendation on it for local farmers at this stage. 
Plantings of root-slips vertically or stem-cuttings at slantingly or vertically are so far successes in local conditions and yields obtained by several workers in various on-farm and on-station conditions are given in Table 03.

Table 02: A fertilizer application program for $\mathrm{CO}-3$ grass

\begin{tabular}{llll}
\hline \multicolumn{1}{c}{ Stage of application } & \multicolumn{1}{c}{ Material } & \multicolumn{2}{c}{ Rate } \\
& \multicolumn{1}{c}{ g/ha } & g/plant \\
\hline Before or at planting & Organic manure & 15,000 & 1.5 \\
& (compost, cow dung or poultry & & \\
& litter) & 200 & 20 \\
$7-10$ days after planting & Urea & 120 & 12 \\
& Triple super phosphate & 100 & 10 \\
& Muriate of potash & 100 & 10 \\
After $1^{\text {st }}$ cut & Urea & 275 & 25 \\
(2 months after & Triple super phosphate* & 225 & 20 \\
establishment) & Muriate of potash* & 100 & 10 \\
After each cutting & Urea** & & \\
(30-45 days intervals) & & & \\
\hline
\end{tabular}

(* applied once for a year or up to $7-12$ cuts.)

Table 03: Green forage yields of CO-3 grass under different management conditions in Sri Lanka

\begin{tabular}{|c|c|c|}
\hline Location & $\begin{array}{l}\text { Forage yield \& management } \\
\text { condition }\end{array}$ & Ref. \\
\hline $\begin{array}{l}\text { Fodder resource center, } \\
\text { Kotadeniyawa }\end{array}$ & $\begin{array}{l}4.69 \mathrm{~kg} \mathrm{DM} / 20 \mathrm{~m}^{2} \\
60 \times 60 \mathrm{~cm} \text { spacing, a cutting at } \\
10^{\text {th }} \text { week after establishment }\end{array}$ & Dassanayake, 2002 \\
\hline $\begin{array}{l}\text { Animal Experimental } \\
\text { Farm, VRI, Gannoruwa }\end{array}$ & $\begin{array}{l}5125 \mathrm{~kg} \mathrm{DM} / \mathrm{ha} / \mathrm{cut} \\
120 \times 120 \mathrm{~cm} \text { spacing, at } 45 \text { days } \\
\text { interval }\end{array}$ & Chamara, 2003 \\
\hline $\begin{array}{l}\text { Animal Experimental } \\
\text { Farm, VRI, Gannoruwa }\end{array}$ & $\begin{array}{l}5.5 \mathrm{~kg} \text { Green/Plant } \\
90 \times 90 \mathrm{~cm} \text { spacing, at } 45 \text { days } \\
\text { interval }\end{array}$ & $\begin{array}{l}\text { Pasture Division,VRI, } \\
2004 \text {,Unpublished }\end{array}$ \\
\hline $\begin{array}{l}\text { Kurunegala } \\
\text { on-farm conditions }\end{array}$ & $\begin{array}{l}8 \mathrm{~kg} \text { Green/Plant } \\
100 \times 100 \mathrm{~cm} \text {, at } 35-40 \text { days } \\
\text { interval }\end{array}$ & $\begin{array}{l}\text { Pasture Division,VRI, } \\
2004 \text {,Unpublished }\end{array}$ \\
\hline $\begin{array}{l}\text { Animal Experimental } \\
\text { Farm, VRI, } \\
\text { Gannoruwa } \\
\text { DM - Dry matter yield; }\end{array}$ & $\begin{array}{l}370 \mathrm{~kg} \mathrm{DM} / 500 \mathrm{~m} 2 \\
100 \times 100 \mathrm{~cm} \text { spacing, at } 45 \text { days } \\
\text { interval } \\
\text { een - Green forage yield }\end{array}$ & $\begin{array}{l}\text { Pasture Division,VRI, } \\
2005 \text {,Unpublished }\end{array}$ \\
\hline
\end{tabular}




\section{Nutrition and feeding of the grass}

Quality of a forage grass is a vital parameter to ensure the fulfillment of all nutritional ingredients for animal. Generally, if an animal are fed with adlib green forages that is grown under good management and cut at correct stage, it can be guaranteed that the animal might take up most of the essential nutrients in sufficient quantities. Studies carried out in Sri Lanka on the nutritional aspects show that this grass is more superior than most of the other farm grown fodder grass. The average figures of the important nutritional components of the herbage of CO-3 grass with NB-21, another hybrid Napier grass that was popular in the past are given in Table 4. These figures indicate the superior quality of the CO-3 grass especially in crude protein, lignin and fiber fractions.

Nilanti et al. (2004) have compared the nutritive composition of CO-3 grass with VRI 435 grass (Panicum maximum var.435), another recommended fodder grass for the Sri Lankan dairy systems. Findings of this experiment also proved the superior quality of the CO-3 grass.

Table 04: Nutritional Comparison of NB -21 and CO-3 grasses

\begin{tabular}{lcc}
\hline \multicolumn{1}{c}{ Nutritional Ingredient } & \multicolumn{2}{c}{ Value (Dry matter basis)* } \\
& $*$ under average management conditions \\
\hline & NB-21 & CO-3 \\
Crude Protein & $10-11 \%$ & $15-16 \%$ \\
Crude Fiber & $27-30 \%$ & $34-37 \%$ \\
Acid Detergent Fiber (ADF) & $39-41 \%$ & $42-47 \%$ \\
Neutral Detergent Fiber (NDF) & $60-65 \%$ & $74-78 \%$ \\
Crude Fat & $5.7-6.2 \%$ & $6.2-6.9 \%$ \\
Ash & $8.2-10.7 \%$ & $9.5-12.8 \%$ \\
Lignin & $9-13 \%$ & $6-8 \%$ \\
Calcium & $0.17 \%$ & $0.11 \%$ \\
Potassium & $0.47 \%$ & $0.42 \%$ \\
Magnecium & $0.21 \%$ & $0.36 \%$ \\
Source: Pasture Division, VRI, 2004, & & \\
\hline
\end{tabular}

\section{Small dairy farmer and C0-3 fodder grass}

Supply of green fodder to dairy animals is not a luxury, but a basic need in order to increase milk production. Presently in Sri Lanka, there is no large scale production of green fodder in most of the dairy production systems. The stall-fed animals depend on outside fodder of low nutritive value. To compensate for this deficiency, concentrates at high costs are being supplied. Unless our farmers could be redirected from this unprofitable practice, Sri Lanka will never reach to a commercial and sustainable milk production.

CO-3 grass produces a lot of highprotein and energy rich forage and this is a real solution for land limited dairy farmers. It can be grown easily as small blocks and even around the cattle sheds, between the vegetable plots and on the contour bunds of the sloppy lands. Under average management conditions, $5 \mathrm{~kg}$ of green fodder per 
bush in every 30 - 45 days could be simply obtained. Growing this grass in small-scale in India, farmers have been able to reach for a considerable economic level from their dairy enterprises.

Department of Animal Production \& Health (DAP\&H) has been introduce the " $500 \mathrm{~m}^{2}$ Fodder Block +2 Milking Cows" concept with $\mathrm{CO}-3$ grass for land limited small farmers. With a spacing of $100 \times 100 \mathrm{~cm}, 500$ number of grass bushes could be planted in a $500 \mathrm{~m}^{2}$ or 20 perches land extent. Providing all necessity inputs for vigorous grass growth followed by other important management aspects, two milking animals could be yearround fed by giving $40 \mathrm{~kg}$ of quality green fodder for each animal.

\section{Current Research \& Development Activities}

In the past, adoption of forage technologies has been poor among the most of farmers in Asian countries. Unfortunately, in Sri Lanka, this issue is still circulating just about a very low level. However, a great success has been achieved in Southeast Asia and east Africa, by revolutionizing research on development of forage technologies for smallholder farmers in the past six years (Roothaert et al., 2003). Therefore, There is an urgent need for strong research/extension/farmer linkage to develop and test the most suitable and adaptable technology under different production systems of Sri Lanka.

\section{Research Activities}

Several categories of experiments (onfarm. on-station, adaptive and farmer participatory) have recently been started by the Pasture Division, Veterinary Research Institute (VRI), to investigate the actual possibilities and limitations of this grass in small dairy holdings, in collaboration with Department of Animal Science, Faculty of Agriculture, and University of Peradeniya. Meanwhile, The Department of Animal Science has been included some experiments on the grass to their postgraduate and undergraduate research program. The investigators of these studies will accept to disseminate the useful findings immediately after confirming, through veterinary officers and livestock development officers of the DAP\&H to the appropriate farmer majority.
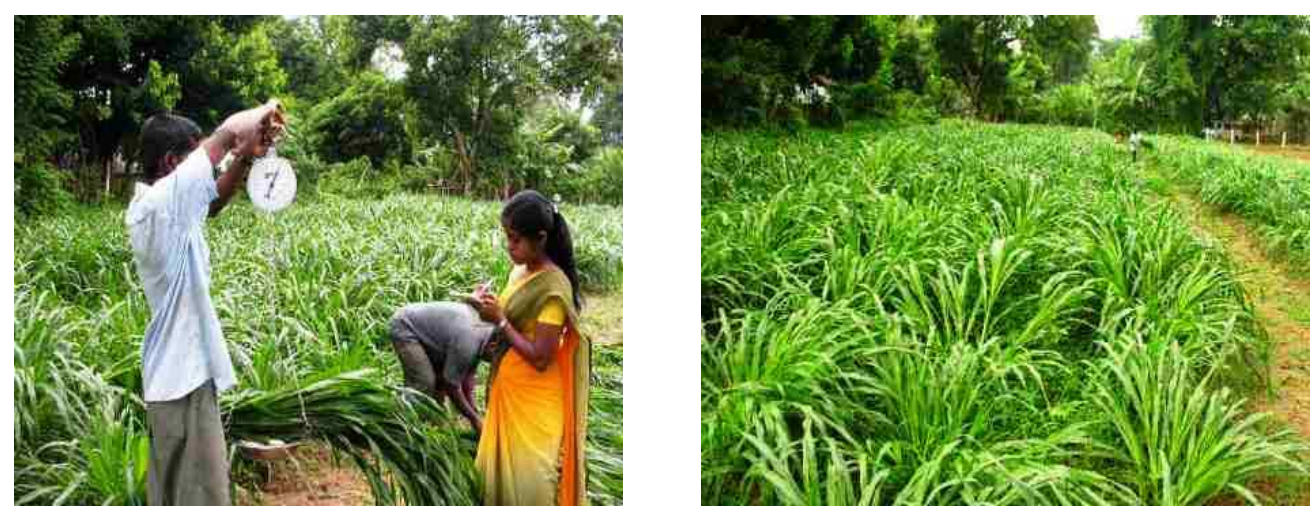

Figure 06: CO- 3 grass studies at VRI experimental station 


\section{Development activities}

Popularizing the grass among small farmers in national level has been initiated from 2000 by the Livestock Breeding Division, (DAP\&H). Production of planting materials, to enhance the green fodder production in small dairyings, introduction of suitable package of practices for different dairy production systems, to conduct training programs for farmers and providing subsidies for farmers are the main objectives of this program. Provincial Directors of DAP\&H provide straight support under regional scale for this effort. In the mean time, Human Resource Development Division of the DAP\&H has started a special training program in "Novel Techniques of Forage Production" with special emphasis on $\mathrm{CO}-3$ grass for the extension officers (Livestock Development Officers) of the department. Further, Fodder Resource Center/Kotadeniyawa and several livestock training centers (Wannigama and Undugoga) of the DAP\&H and few livestock farms of the National Livestock Development Board (NLDB) are parallely producing quality planting materials.

\section{CONCLUSION}

Resembling the other Asian countries, Sri Lanka needs to increase the milk production in the country up to a considerable level within next 5 years. It is very clear that this target must combine with good quality green forages. CO-3 grass is an important fodder grass that produces a lot of high-protein and energy rich forage and, this is a real way out for land limited dairy farmers. To popularize this grass among the majority of dairy farmers, it must be strengthen each category of the development activities on this fodder grass among all responsible and relevant institutions in the country.

\section{ACKNOWLEDGEMENTS}

The authors are grateful to Ms. Charika Bandara, Research Assistant, Pasture Division, VRI; Mr. Anil Jayawardena and Mr. D.M.W.K. Dassanayake, Livestock Development Officers, DAP\&H; and Mr. W.W.S.Chamara (past undergraduate student of authors) for providing some useful information for this review paper.

\section{References}

Annual report, 2002. Livestock Breeding Project (LBP), Ministry of Agriculture \& Livestock, Sri lanka.

Bogdan, A.V. (1977) Tropical Pasture and Fodder Plants. Longman Group Limited, London. pp $233-244$.

Chamara, M.W.S., S. Premaratne,. and G.G.C. Premalal, (2003) On-farm management and persistence of hybrid Napier (Pennisetum perpureum x P. americanum var. CO-3) grass at Kurunegala district. In: Proc. $11^{\text {th }}$ Annual students research sessions, Dept. of Animal Science, Univ. of Peradeniya, 2003. pp 61-62.

Dassanayake, D.M.W.K., (2002) Performance of CO-3, Clone-13 and NB-21 fodder varieties grown under field conditions at Kotadeniyawa Fodder Resource Center. Final year project report (B.Sc. Agric), Dept. of Animal Science, University of Peradeniya, Sri Lanka. 
Gupta, S.C. and O.Mhere, (1997). Identification of superior pearl millet by Napier hybrids and napiers in Zimbabwe. African Crop Science Journal, 1997, Vol. 5. No.3, pp. 229-237.

Jayanthi, C. (2003) Productivity of Bajra-Napier hybrid grass under different planting methods and time of fertilizer applications. htpp://www.tnau.ac.in/scms/agronomy/jayanthi.htm.

Narayanan, T.R. and P.M. Dabadgho, (1972). Forage crops of India, Indian Council of Agricultural Research, New Delhi.

Nilanthi, J., S. Premaratne and G.G.C. Premalal, (2004). Yield and nutritive value of Napier Hybrid (CO-3) and Guinea grass (VRI-435) as affected by fertilizers. In: Proc. $12^{\text {th }}$ Annual students research sessions, Dept. of Animal Science, Univ. of Peradeniya, 2004. pp 13 - 14.Pasture Division, veterinary Research Institite, Gannoruwa, Peradeniya.

Pathirana, K.K., (1970) Napier Grass - A review, Animal Production and Health Bulletin. Vol. 4. pp $110-121$.

Policy Note (2005/2006), Animal Husbandry Department, Government of Tamil Nadu. http://www.tn.gov.in/policynotes/animal.htm

Roothaert, R., P.Horne, and W.Stur, (2003). Integrating forage technologies on smallholder farms in the upland tropics. Tropical Grasslands, Vol. 37, pp102107.

Sidhy, B.S. (2003). Fodder hybrid that need promotion. "The Tribune”, Online Edition, Monday, April 7, 2003. http://www.tribuneindia.com/2003/200330407/agro.htm\#1

Tambukiza (2002), htpp://www.kari.org/default.htm

Thairu, D.M. and S.Tesema, (1985). Research on animal feed resources; Medium potential areas of Kenya. In: Animal feed resources foe small scale livestock producers. Proc. The second PANESA workshop, 11- 15 Nov. 1985, Nirobi, Kenya. pp. $127-137$.

TNAU (Tamil Nadu Agricultural University) 2003, www.tnau.ac.in

Walmsley, D., V.A.L. Sargeant, \& M.Dookeran, (1978). Effect of fertilizers on growth and composition of elephant grass (Pennisetum purpureum) in Tobago, West Indies. Trop. Agric. (Trinidad), 25: 329-334. 